\title{
超音波パルスの人体モデル内に打ける骨， 脂肪組織打よび空気層からの影暗
}

\author{
中村 修 ${ }^{1)} \cdot$ 森田長吉 $^{1)} \cdot$ 岡崎 清 $^{2}$
}

1 ) 千葉工業大学

2) (株) 東芝・医用機器技術研究所

1996 最終論文受理

Code No.762

\section{1. はじめに}

電磁界数值解析法の一つである有限差分時間領域法 (FD-TD法 $)^{1-3)}$ の基本的な考え方は超音波伝搬の解析 にもそのまま応用できる4 - ，そこで筆者らはこの方法 を用いて，これまで，体外衝擊波結石破砕装置(Extracorporeal Shock Wave Lithotriper : ESWL)のエコート リガ照射機構10 12)で用いる弱い集束超音波パルスの人体 モデル内伝搬の様子を詳細に解析し，エコートリガパ ルスの動作特性を種々の観点から検討してきた13〜17).

本稿では, 非線形性の伴わない弱い集束超音波パル ス伝搬路の焦点部にターゲットとしての結石を置き， 超音波パルスの伝搬路付近の骨組織，脂肪組織扔よび 空気層が存在する場合について, パルスの伝搬の様子 を時間領域で数值解析して詳しく調べ，これらの領域
の存在が集束超音波パルスの伝搬等にどのように影響 するかを検討すると共にその可視化を試みる。

\section{2. 解析手法}

使用する基本方程式は次の2式である ${ }^{13 \sim 17)}$.

$$
\begin{aligned}
& -\nabla \mathrm{P}=\rho \frac{\delta \mathbf{V}}{\delta \mathrm{t}} \quad \ldots \ldots \ldots \ldots . . . \\
& -\frac{\delta \mathrm{P}}{\delta \mathrm{t}}=\mathrm{K} \nabla \cdot \mathrm{V}+\mathrm{KSP} \\
& \text { ただし, }
\end{aligned}
$$

$\mathrm{K}=\rho \mathrm{C}^{2}$

であり，Pは音压，Vは粒子速度，Cは音速，Kは体積

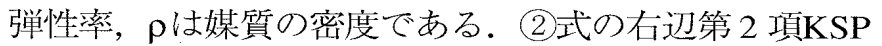

\section{Influence from Bony Structures, Fatty Tissues and Air Areas of Ultrasonic Pulses in Human Model}

\author{
OSAMU NAKAMURA ${ }^{1)}$ • NAGAYOSHI MORITA ${ }^{1)}$ • KIYOSHI OKAZAKI')
}

1 ) Chiba Institute of Technology

2) Medical Engineering Laboratory, Toshiba Corporation

\section{Summary}

We have analyzed so far, by using the finite-difference time-domain method, the propagation and scattering in the human body model of weak converging ultrasonic pulses which are utilized in echo trigger pulse systems equipped with extracoporeal shock wave lithotripter, and have investigated, on the basis of this analysis, the operational property of the echo trigger pulse system. In this paper, we analyze the scattering and reflection of weak converging ultrasonic pulses by a renal calculus in the focal region, and bony structures, fatty tissues and air areas near around pulse propagation paths to investigate the effect of the existence of those obstacle areas on the operation of trigger pulse system.

Key words: Ultrasonic pulse, Medical ultrasonic wave, Numerical analysis, Propagation, Lithotripter, Reflection wave. 
は損失を表す項であり，KSは(3)式から

$$
\mathrm{KS}=\rho \mathrm{SC}^{2}\left[\frac{1}{\mathrm{sec}}\right]
$$

と表すことができる、計算にあたっては，まず，計算 領域内にP抢よびVの值を与える点を格子状にとびと びに配置し，時間的にもこれらを $\mathrm{t}$ という間隔で離散 的にとる。また，PとVを空間的にも時間的にも交互に とるようにする。このように決めたP抢よびVの離散的 な值を用いて基本式(1)，(2)式の差分近似式を導出す る、いま $x_{\mathrm{m}}$ を計算領域の横方向 $(x$ 方向 $)$ の長さ， $y_{\mathrm{m}}$ を 縦方向 $\left(y\right.$ 方向)の長さとした場合， $x_{\mathrm{m}}$ を $\delta x$ の間隔で, $y_{\mathrm{m}}$ を $\delta \boldsymbol{y}$ の間隔で格子状に分割し， $\mathrm{P}$ と $\mathrm{V}_{\mathrm{x}}$ 拈よび $\mathrm{P} と \mathrm{~V}_{\mathrm{y}}$ を $x$ 扮よびy方向に交互に配置することになる。このよう に配置したPと $\mathrm{V}_{x}, \mathrm{~V}_{\mathrm{y}}$ とを，導出した差分式を用い て， $\frac{1}{2} \delta \mathbf{t}$ という時間間隔で交互に計算していく13-17). 本論文でもこれまでの文献と同様，計算が複雑になる 3 次元問題のかわりに計算時間が短縮できる 2 次元問 題として取り上げる。

\section{3. 解析例}

Fig. 1 (a)の腎結石症患者のX線CT画像，Fig. 1 (b)に それを図式化したものを示す. Fig. 1(b)には実際の超 音波励振用アプリケータの位置も示している。この例 ではアプリケータの振動子より発射させた超音波が結 石に達するまでの伝搬路内に胁骨(以下骨という)が存 在していることがわかる.Fig. 2 はFig. 1 (b) を参考に して作った同図の単純化モデル 4 例である.どの例も $0<\boldsymbol{x}<\boldsymbol{x}_{\mathrm{m}}, 0<\boldsymbol{y}<\boldsymbol{y}_{\mathrm{m}}$ の四角形領域が人体に相当する領域 であり，これが計算領域である。計算領域の中心に円 形の結石がある。また，計算領域の左側に結石を中心 とする2つの太線の円弧が示されているがこれらは体 外に配置される圧電子の振動子面のモデルである.

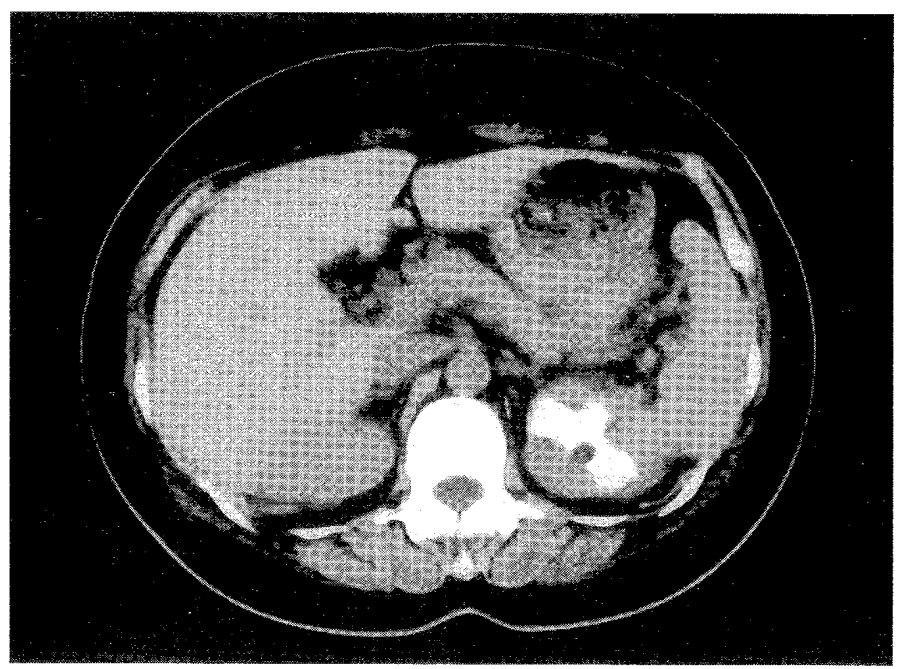

(a)

Fig. $1 \times$ ray CT imaging (a) of a renal calculus disease patient and its schematic drawing (b) $\boldsymbol{x}<0$ (人体外)の部分は温水が充填される領域となる. この領域に関しては振動子から発射される実際の複雑 な超音波パルスを再現できるような厳密な解析を行うこ とは極めて難しい，そこで本研究では次のような簡単な 方法を採用し， $x<0$ の領域を計算領域から外す13-17). すなわち，超音波励振パルスを左端の円弧状振動子上 に与えるかわりに，y軸上の ab， cd上に(Fig. 2 (a) 参照) 与えることにする. 励振パルスの波形をFig. 3 に示 す。関数形は省略する $14,16,17)$. Tは基本振動周期であ る。また， $x<0$ の部分は非線形18,19) も衰退もない領域 とし, この領域の音速Cは $x<0$ の領域の音速と同じと

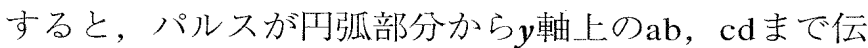
搬する際に生じる位相遅れは近似的に伝搬距離に比例 すると考えられる。只こで，円弧上で同位相でパルス を与えたとし $\mathrm{ab}$ ， cdでは备部で位置遅れを加味したパ ルス波形を与える．以下の解析例でもこれらの条件は すべて同じである。

Fig. 2(a) は，超音波伝搬路内に何も障害物がない場 合であり，Fig. 2(b) は励振部側に厚い脂肪組織があ り，結石側に薄い脂肪組織が存在する場合である。ま た，Fig. 2(c)は(b)の脂肪組織に加えて骨が上下に存在 する場合であり，Fig. 2(d)は(b)の脂肪組織に加えて 容量約70ccの空気層が存在する場合である. Fig. 1 で は伝搬路内に空気層が存在しないが，Fig. 2(d)ではと くに空気層がある場合を想定している. (4)式のKSは 一般に周波数の関数であるが，本論文では数值計算で 用いる励振パルス波形の中心周波数は約 $0.3 \mathrm{MHz}$ であ るので14, 16, 17)，本論文では近似的にこの周波数に扔け る值を用いる。各組織の測定値 ${ }^{20)}$ に基づいて $0.3 \mathrm{MHz}$ での KSの值を求めると筋組織は $5.9 \mathrm{CM}$, 結石は $267.0 \mathrm{CC}$ ，脂肪組織は8.8CF，骨は200.0Cв，空気層は 5.3C $\mathrm{A}$ となる。ここで添字， M， C， F， B，Aはそれぞ 扎筋組織, 結石, 脂肪組織, 骨, 空気層を意味する。

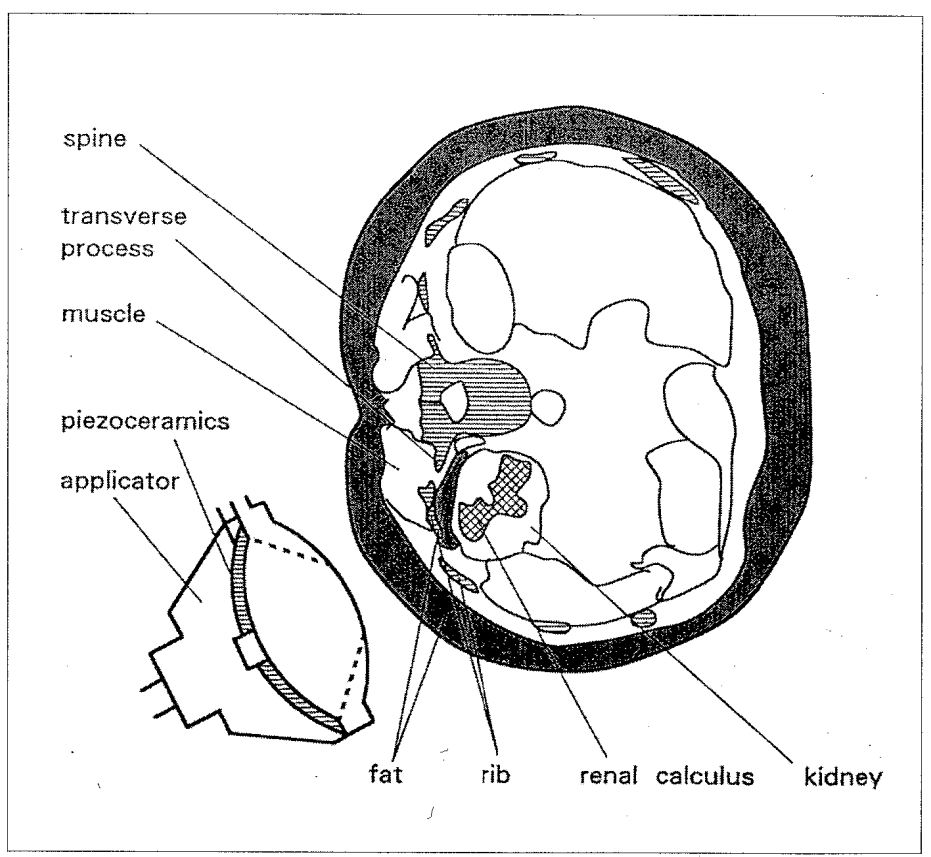

(b) 

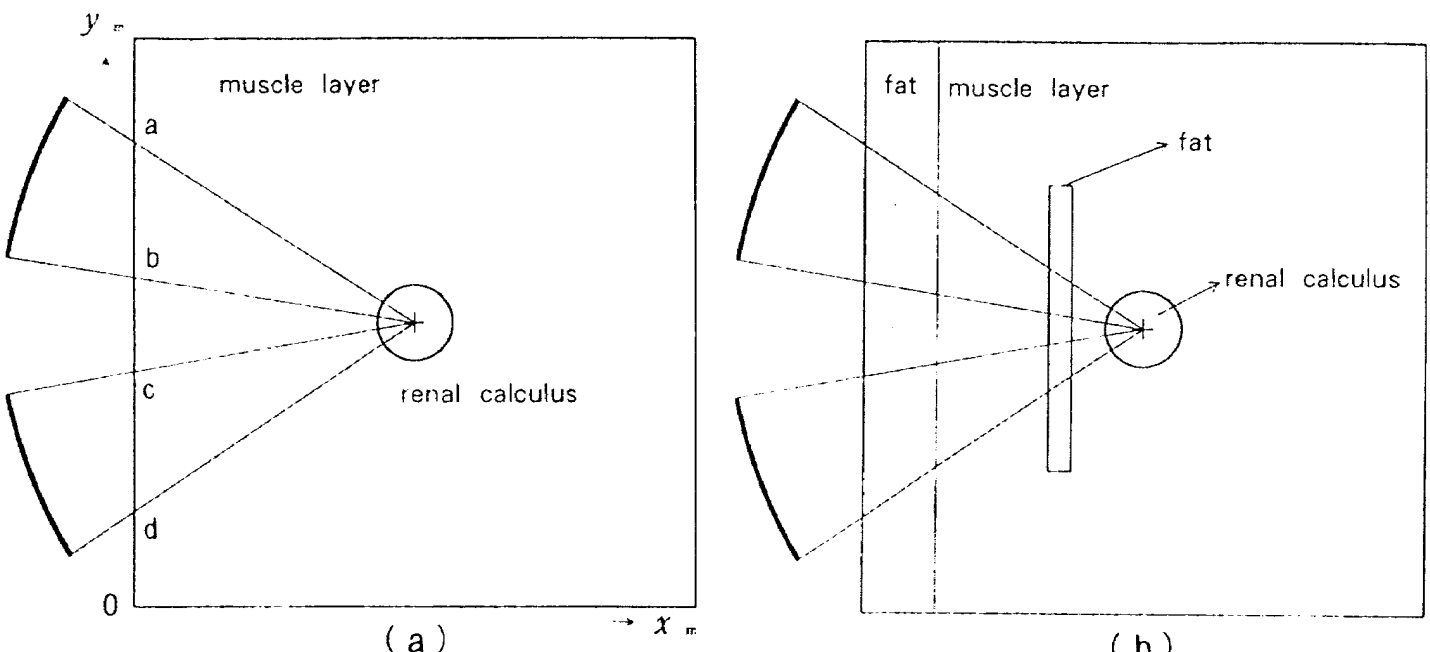

(b)
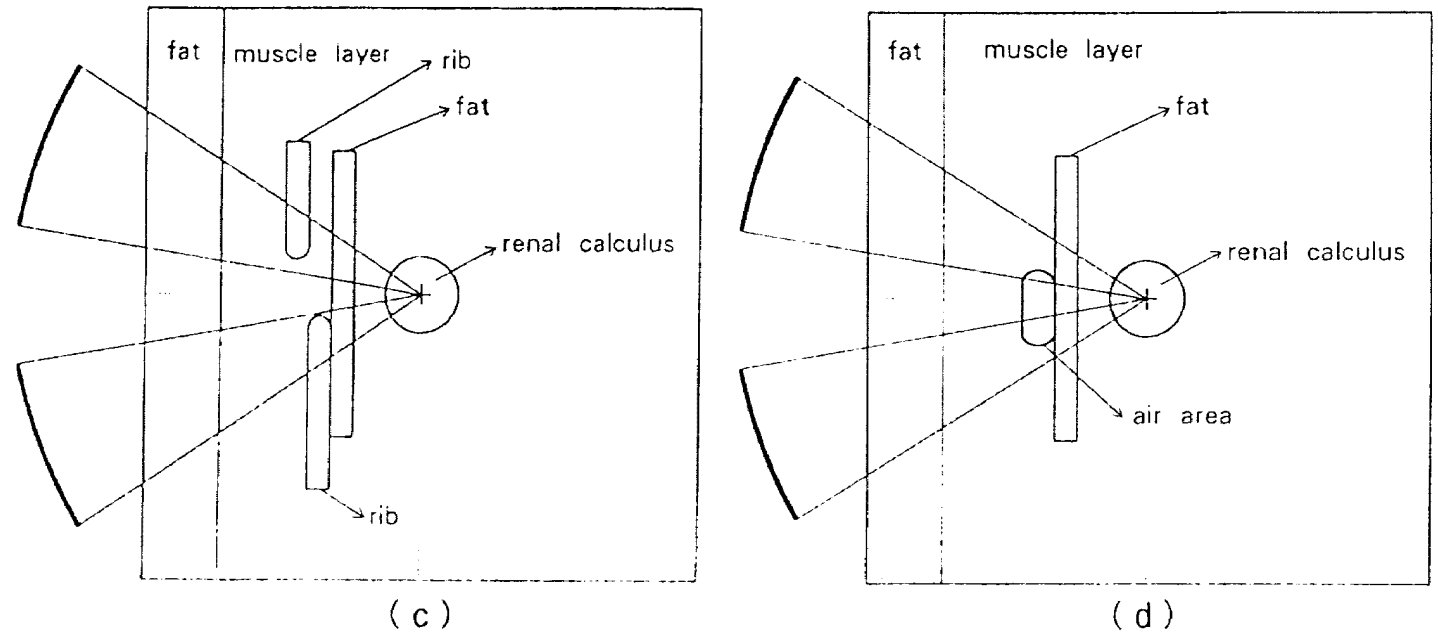

(d)

Fig. 2 Models for analysis

(a) No obstacles inside the propagation paths

(b) Existence of fatty tissues inside the propagation paths

c) Existence of fatty tissues and bony stuctures inside the propagation paths

(d) Existence of fatty tissues and air area inside the propagation paths

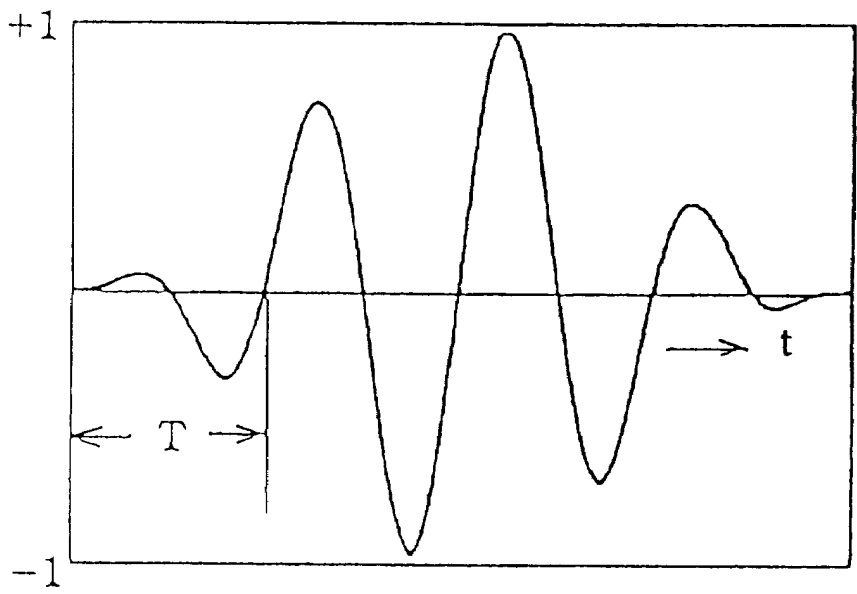

Fig. 3 Excitation function 
また，数值計算で採用する空間，時間に要するパラメ 一夕は以下のように運ぶ。

$$
\begin{aligned}
& \boldsymbol{x}_{\mathrm{m}} \times \boldsymbol{y}_{\mathrm{m}}=120 \mathrm{~mm} \times 120 \mathrm{~mm} \\
& \delta \boldsymbol{x}=\delta \boldsymbol{y}=0.5 \mathrm{~mm} \\
& \mathrm{~T}=3.3 \mu \mathrm{sec}, \quad \delta \mathrm{t}=\frac{\mathrm{T}}{50.0}
\end{aligned}
$$

また，各組織の媒質定数としては次の值 ${ }^{20)}$ を用いる.

$$
\begin{array}{ll}
\mathrm{C}_{\mathrm{M}}=1,560 \mathrm{~m} / \mathrm{s}, & \mathrm{C}_{\mathrm{C}}=3,000 \mathrm{~m} / \mathrm{s} \\
\mathrm{C}_{\mathrm{F}}=1,460 \mathrm{~m} / \mathrm{s}, & \mathrm{C}_{\mathrm{B}}=2,500 \mathrm{~m} / \mathrm{s} \\
\mathrm{C}_{\mathrm{A}}=340 \mathrm{~m} / \mathrm{s}, & \rho_{\mathrm{M}}=1.07 \mathrm{~g} / \mathrm{cm}^{3} \\
\rho_{\mathrm{C}}=1.40 \mathrm{~g} / \mathrm{cm}^{3}, & \rho_{\mathrm{F}}=0.92 \mathrm{~g} / \mathrm{cm}^{3} \\
\rho_{\mathrm{B}}=1.38 \mathrm{~g} / \mathrm{cm}^{3}, & \rho_{\mathrm{A}}=0.00119 \mathrm{~g} / \mathrm{cm}^{3}
\end{array}
$$

これらの数值は生体の筋組織, 結石, 脂肪組織求よ び骨組織から直接測定された值ではないので必ずしも 厳密なモデルではない。なお，本方法では空間分割の メッシュ点がどの領域にあるかによって媒質定数が個 々に与えられるので, 各組織どうしの領域の境界での 境界条件は設定する必要がない。

\section{4. 計算結果}

Fig. 4 はFig. 2(a)の解析モデルで焦点部の結石が直径 $16 \mathrm{~mm}$ の円であるときの各時刻に扔ける音圧分布であ る. Fig. $4(\mathrm{a}-1) \sim(\mathrm{a}-6)$ は中心軸上(Fig. $2(\mathrm{a})$ の $\left.y=\frac{\mathrm{y} \mathrm{m}}{2}\right)$ の時間波形であり，Fig.（b-1) （b-6）はその濃淡表 示である.Fig. 4(a)の横軸の単位はmmであり, 縦軸 は励振関数 ${ }^{13 \sim 17)}$ の最大振幅を 1 として計算して得た 值であり，単に相対的な大きさを意味するだけであ

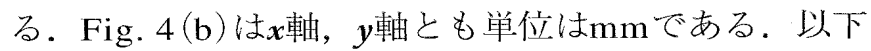
の図でも同様である。Fig. 5 はFig. 2(b)の解析モデ ルの場合の音圧分布である。Fig. 5(b)の点線は脂肪 組織を示している.Fig. 6 はFig. $2(\mathrm{c})$ の解析モデル の場合の音圧分布である。Fig. 6(b)の実線部分は骨 を示している.Fig.7 はFig. 2(b) の解析モデルの場 合の音圧分布である。Fig. 7(b)の実線部分は些気領 域を示している。

\section{5. 考察}

まず，超音波伝搬路内に何も障害物がないFig. 40 場合について考察する。Fig.4の(a-1) （a-6)の時間波 形を見ると集束効果によりパルスが焦点に向かって進 むに従い徐々に波形が大きくなっている．Fig. 4(a-4) では超音波パルスが結石に衝突した瞬間，急に大きく なっている。また, 結石内の超音波の伝搬も観察でき る.Fig. 4(a-5)では結石からの反射波と結石内の超音 波の伝搬がさらに多くなっているのがわかる：Fig４ (a-4)では衝突後の反射波がよく観察され，反対側に も小さなパルスが見られる.Fig. 4(b-1) 〜 (b-3)の濃淡 図では伝搬してきた超音波パルスが中心の結石に问か って集束していく様子がよくわかる. Fig. 4(b-4)， Fig. 4(b-5)では結石に超音波パルスが衝突した瞬間や 結石内部の伝搬, 結石からの反射等が定性的によく示 されている. Fig. 4(b-6)では散乱波の分布が180方向

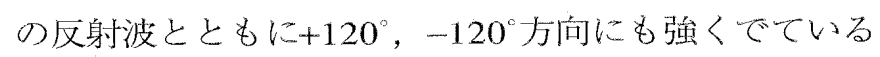
ことがわかる。この例の場合, 結石からの反射波は比 較的多くなっている。次にFig. 5 の脂肪組織力存在す る場合について見てみると，集束の様子はFig. 4 の場 合とあまり変わらないがFig. 5(a-4)の結石に衝聟した 瞬間の音圧ピークの大きさがFig. 4 のそれと比へて相 当小さい。また，Fig. 4 とFig. 5 の超音波パルスの進 行の様子を比較してみるとFig. 5(a-2)，(a-3)ではFig. 4 のそれより遅れており, 全体としてパルスの振幅も 小さい。これらの現象は脂竻の場合筋肉組織よりも音 速が小さいこと抢よび吸収が大きいことから容易に理 解される。Fig. 5(a-4)，（a-5）では薄い脂肪組織からの 反射波か確認できる。Fig. 5(a-6)に見られる衝突後の 反射波はFig.4(a-6)に比べてそれはど小さくない。た た，Fig.4の場合に比ベパルスの進行の遅れが観察さ れる。超音波パルスの結石内の伝搬, 散乱, 反射の様 子はFig. 4 と類似している.Fig. 5 の例から脂肪組織 が超音波パルスの伝搬に多少影響を与えることがわか るが，その影響がそれほど大きくない.Fig.60超音 波伝搬路内に骨組織が図のように存在する場合を次に 見てみると，Fig.6(a-1)，(a-2)についてはFig.4，5と あまり変わらないが, Fig. 6(a-3)，(b-3)では骨から大 きな反射波が生じており，Fig.6(a-4)，(b-4)では結石 に衝突する超音波パルスの大きさがかなり小さいのが わかる. Fig. 6(a-5)，(a-6)，(b-5)，(b-6)でも骨から の反射波が支配的であり結石からの反射波はほとんど 確認できない。また，Fig.6(b-3)では骨の間隍を縫っ てパルスが伝搬している様子が明暸に確認でき，Fig. 6(b-4)，(b-5)では骨の先端を中心として反射波が広 がっていっているのが確認できる。Fig.6(b-6)では結 石からの反射波が $120^{\circ} ，-120^{\circ}$ 方向に確認することが できるが $180^{\circ}$ 方向の反射波はほとんど確認できない. 最㣪にFig. 7 の超音波伝搬路内に図のような位置に空 気層が存在する場合を見てみると，Fig.7(a-2)，(b-2) で既に空気層からの反射波，散乱波が生じて拉り， Fig. 7 (a-3) (a-5)，(b-3) ( b-5)では筀気層の上部を まわり达んで通過した超音波パルスが結石に到達して いるのか確認できる。Fig.7 (a-6)，(b-6)も結石からの 反射波が空気層からの反射波に比心゙非常に少ない.

Fig. 7(b-2)を見ると当然ながら空気層の内部へのパル スの進入はない。これらのことからも空気層が完全な 反射体に近いことがよく観祭される。Fig.7(b-6)では 空気層からの散乱と結石からの散乱とが重なって興味 深い濃淡模様を呈している。

\section{6. むすび}

時間領域数值計算法を用いて弱い集束超音波パルス の人体内伝搬の問題を解析した。 とくに脂肪組織, 骨，結石の位置を案際の症例に基づいて設定した場 合，および脂肪組織，結石に加えて空気層を設定した 場合を解析し，骨領域，脂肪組織抢よび空気層の存在 が集束超音波パルスの伝搬等に及ばす影響を検討し， 更に，可視化することを試みた。 
Fig. 4 Waveform on the central axis ( (a-1)$(a-6))$ and density plot $((b-1)-(b-6))$ of sound pressure at each time for the case where no obstacles are inside the propagation paths (The case of Fig. 2a)
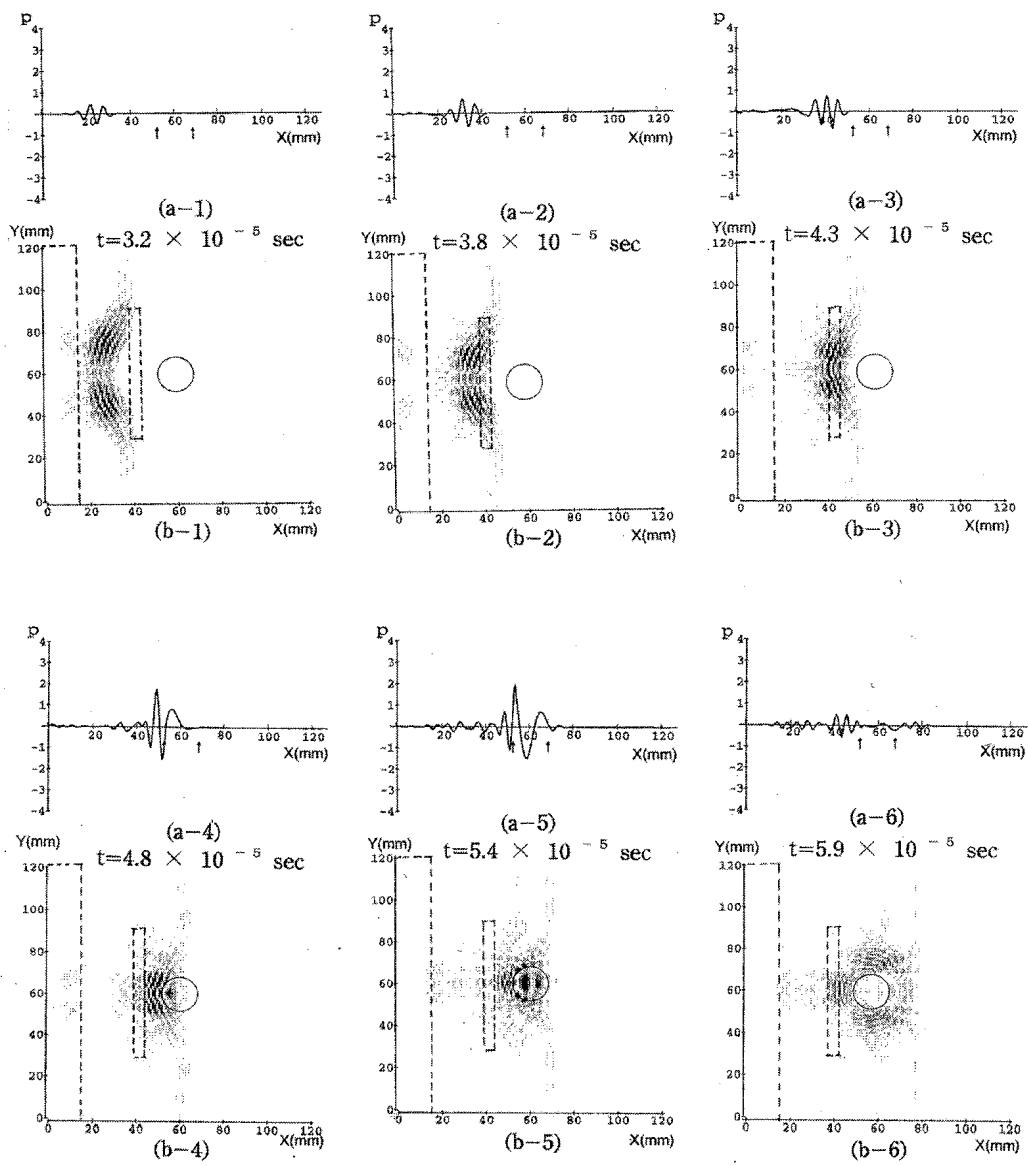
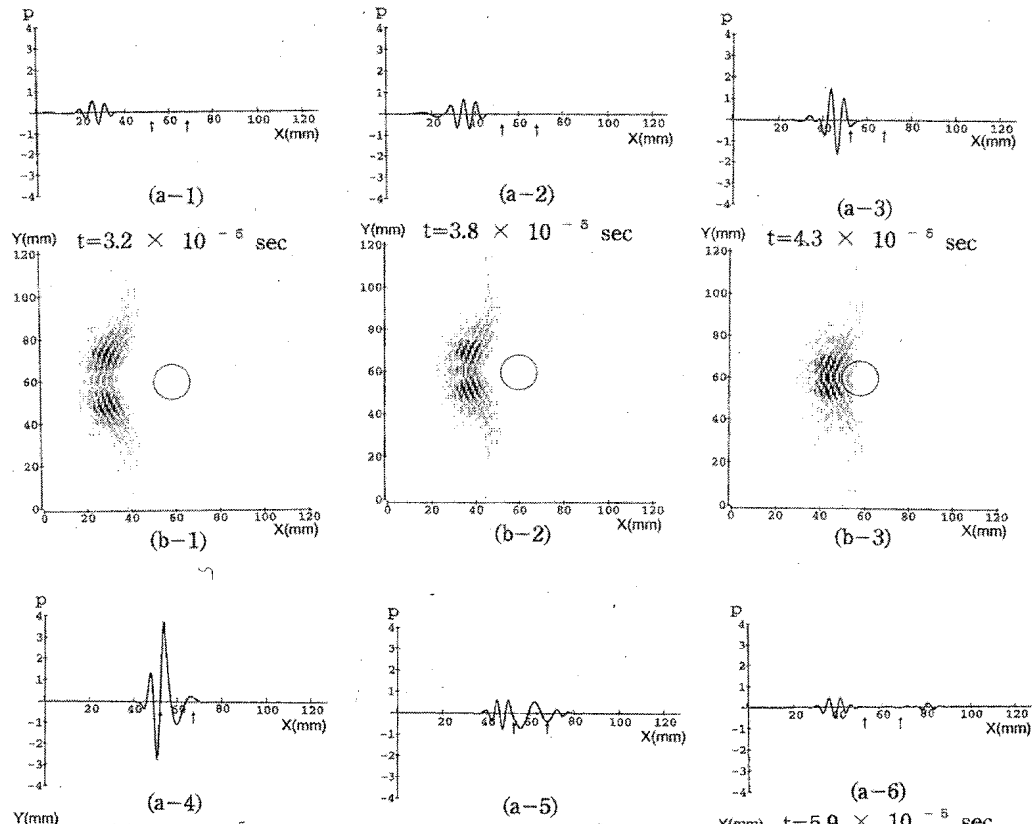

$\left.{ }^{Y(m o t)}\right) \mathrm{t}=4.8 \times 10^{-5} \mathrm{sec}$
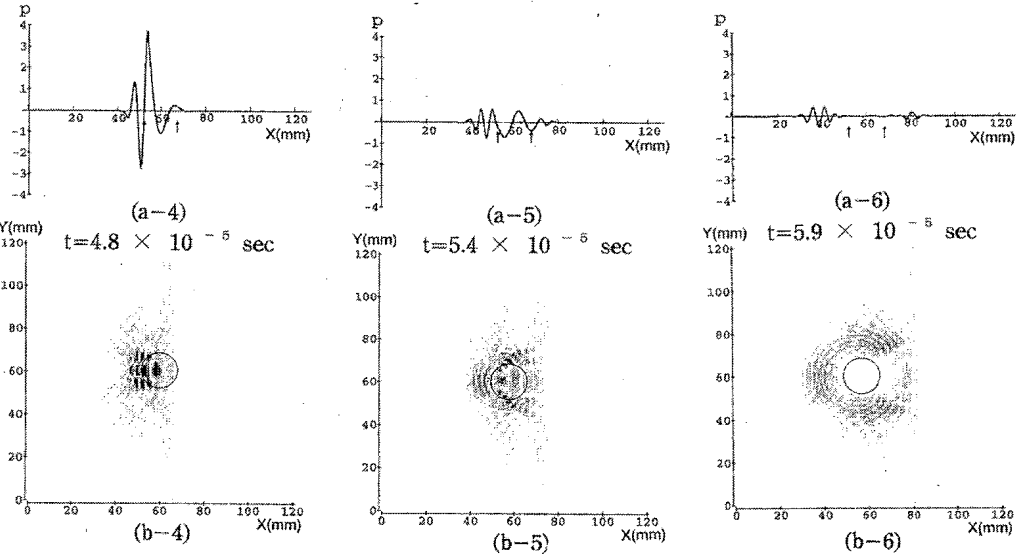

Fig. 5 Waveform on the central axis ( (a-1) $-(a-6))$ and density plot $((b-1)-(b-6))$ of sound pressure at each time for the case where fatty tissues are inside the propagation paths (The case of Fig. 2b) 

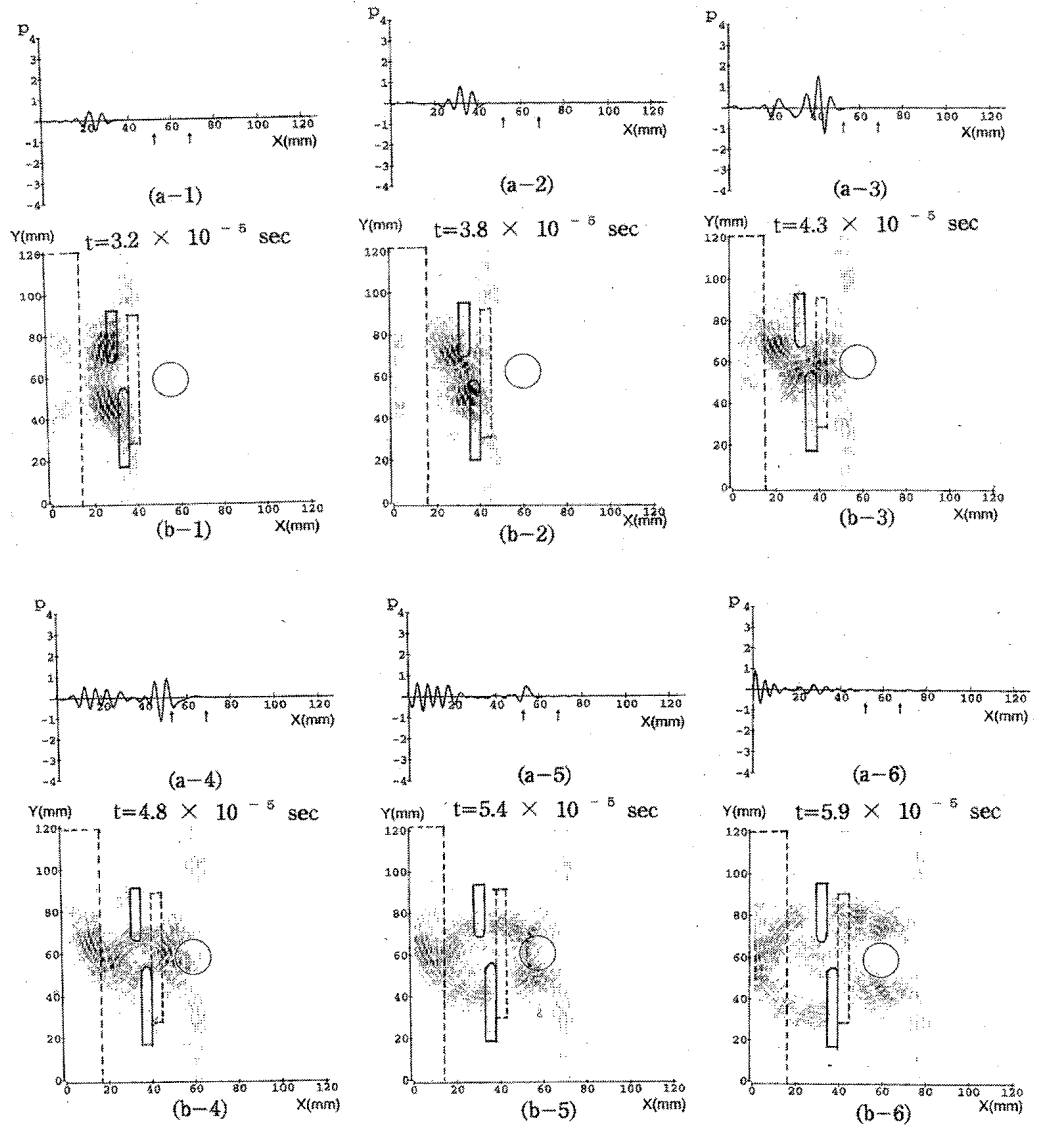

Fig. 6 Waveform on the central axis ( (a-1)$(a-6))$ and density plot ( (b-1)-(b-6)) of sound pressure at each time for the case where fatty tissues and bony structures are inside the propagation paths (The case of Fig. 2c)
Fig. 7 Waveform on the central axis ( $(a-1)$ $(a-6))$ and density plot $((b-1)-(b-6))$ of sound pressure at each time for the case where fatty tissues and air area are inside the propagation paths (The case of Fig. 2d)
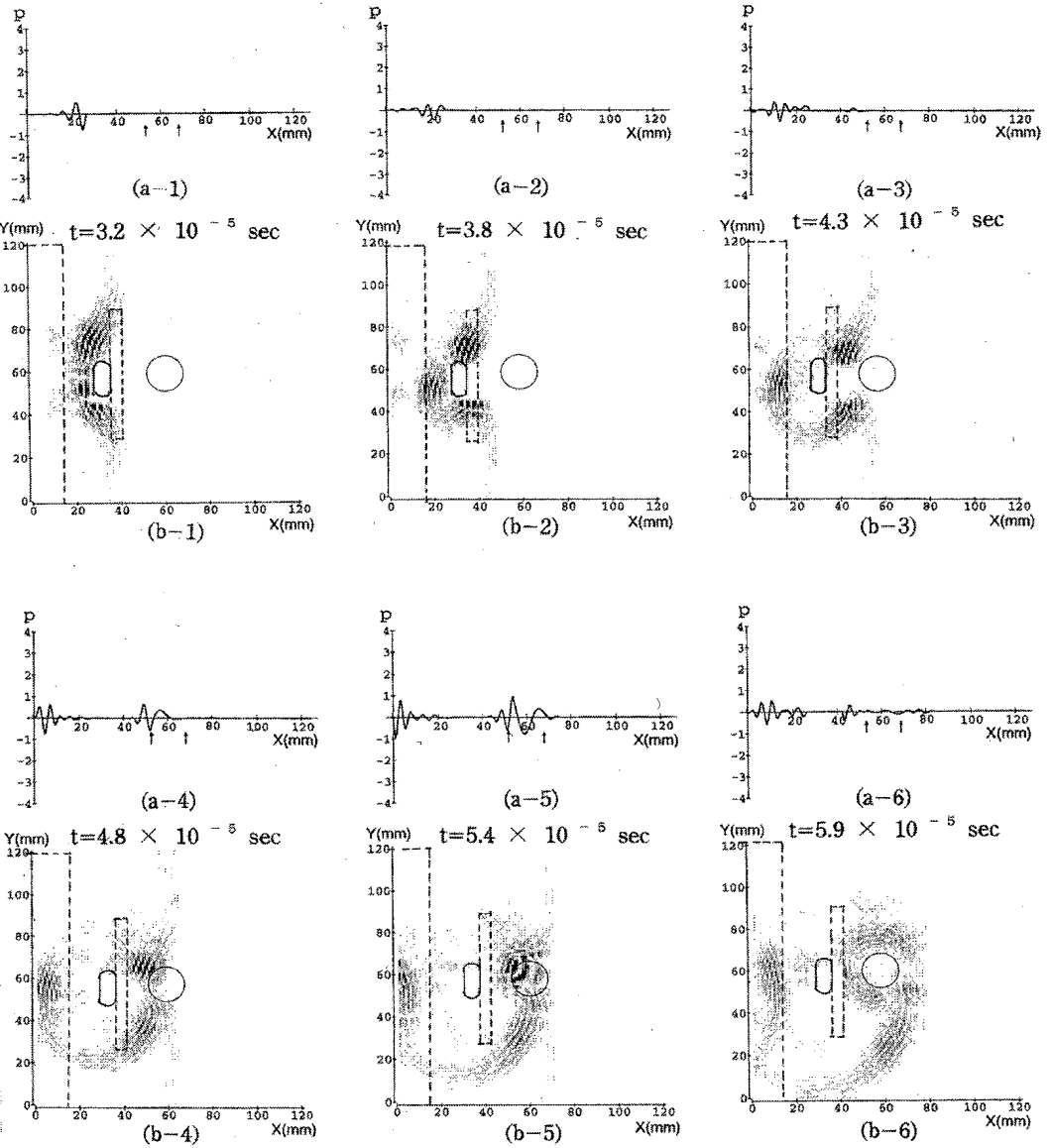
この結果，脂肪組織が筋組織と比心゙超音波パルスの 伝搬がどの程度遅れ，またどの程度吸収が多いかを確 かめることができた。また，骨組織の内部を相当量の 超音波パルスが透過することおよび空気領域は完全な 反射体に近いことも確かめられた。さらに脂肪組織の 存在は反射パルスの大きさにはほとんど影響を与えな いこともわかった。この様な方法で，集束超音波パル スの人体内伝搬の様子を詳しく解析することで，超音
波を用いたモダリティに関する色々な問題の解析の端 著になり得ることを期待するものである。

本稿では結石が円形であったが，種々の形の結石 についても検討すること，また，結不の付近に別な 組織を置いて考察すること，更に3次元問題として解 析すると，非線形問題を検討すること等も今後の課 題である。

\section{参考文献}

1) K.S.Yee: Numerical solution of initial boundary value problem involving Maxwell's equiations inisotropic media, IEEE. Trans. on Antennas \& Propag. Vol. AP-14, No.3, 302-307, (May 1993).

2) A. Tafove and K.R.Umashankar: The finite-difference timedomain method for numerical modeling of electromagnetic wave interaction with arbitary structures, in M.A.Morgan, ed.,: Finite Element and Finite Difference Method in Electromagnetic Scattering, Chapter 8, Elsevier, 1990.

3) A.Taflove: Review of the formulation and application of the finite-difference time-domain method for numerical modeling of electromagnetic wave interactions with arbitary structures. Wave Motion, Vol. 10, 547-582, 1988.

4）柏 達也，秋田博正，霜田英麿，他：ベクトル量を用いた 音響時間領域差分法とその散乱解析への応用。信学論, J74-A, 1113-1115, (1991).

5) 千葉 修, 柏 達也, 霜田英麿, 他：リープフロッグアル ゴリズムに基ずく時間依存差分法による3次元音場解析. 日本音響学会誌，No.49,8,551-562，(1993)。

6) 松田利成，保木文秋，羽田野 甫：軸対称モデルによる弾 性波伝搬の差分法シミュレーション，信学技報，US94-13， (1994-07)

7) C.H.Chaussy, W.Brendel, E.Schiedt: Extracorporeally induced destruction of kidney stones by shock waves, Lancet II: 1265 , (1980).

8) C.H,Caussy: Extracorporeal shock wave lithotripsy, Karger, Barsel, (1982).

9) L.V.Kandel, L.H.Harrison, D.L.McCullough: State of the art ESWL, Futura Pub. Co., N.Y., (1987).

10) 岩間信幸, 岡崎 清, 野村 哲, 他：対外衝撃波結石破砕 に扔ける譢照射防止機能の有用性の検討，JSUM. Proceed- ing, 191-192, (Oct. 1990).

11）岡崎 清, 岩間信幸, 野村 哲, 他：対外衝撃波結石破砕 における誤照射防止機能の有用性，第 1 回超音波エレタト ロニクスの基礎と応用に関するシンポジュウム講演予稿 集. 京都，120-121，(Nov. 1990).

12) N.Ioritani, S.Orikawa, M.Kuwahara: The correct targeting rate in ESWL treatment measured by an anti-miss-shot control device, Jpn J Endourology and ESWL, Vol.3. No.2, 179-186, (1990).

13）中村 修, 森田長吉, 岡崎 清: 超音波パルスの生体媒質 内伝搬と焦点への集束過程の数值シミュレーション，信学 技報，US94-13，25-32，(1994-05)。

14）中村 修, 森田長吉, 岡崎 清: 超音波パル久の腎結石か らの反射波に及ぼす骨技上び脂肪領域の影響。信学技報, US94-26, 47-54, (1994-07).

15) 中村 修, 森田長吉, 岡崎 清: 超音波パルスの人体モデ ル内に扮ける伝搬・集束過程の数值シミュレーションと観 測。日放技学誌，51(2)，131-140，(1995).

16）中村 修, 森田長吉, 岡崎 清: 体外衝撃波結石破砕装置 に㧍けるエコートリガパルスの伝搬㧍よび散乱の理論的検 討，医用電子と生体工学，Vol.33 No.1，32-39，(1995).

17）中村, 修, 森田長吉, 岡崎 清: 超音波結石破砕治療装置 に抬けるトリガパルス反射波の定量的評価. 信学諭, Vol.J78-A, No.10, 1263-1275, (1995).

18）高山和喜：衝撃波の扔はなし，日本規格協会，（1990）。

19) K.Okazak, N.Iwama and S.Nomura: Process change of fróm ultrasonic wave to shock wave lithotripsy using piezoceramic transducer. Jpn J Appl Phys, Vol.30-1, 216-218, (1991).

20) B.R.Roberr: Ultrasonic heating technique. NATO Ser E, 127, 390-401, (1987). 